


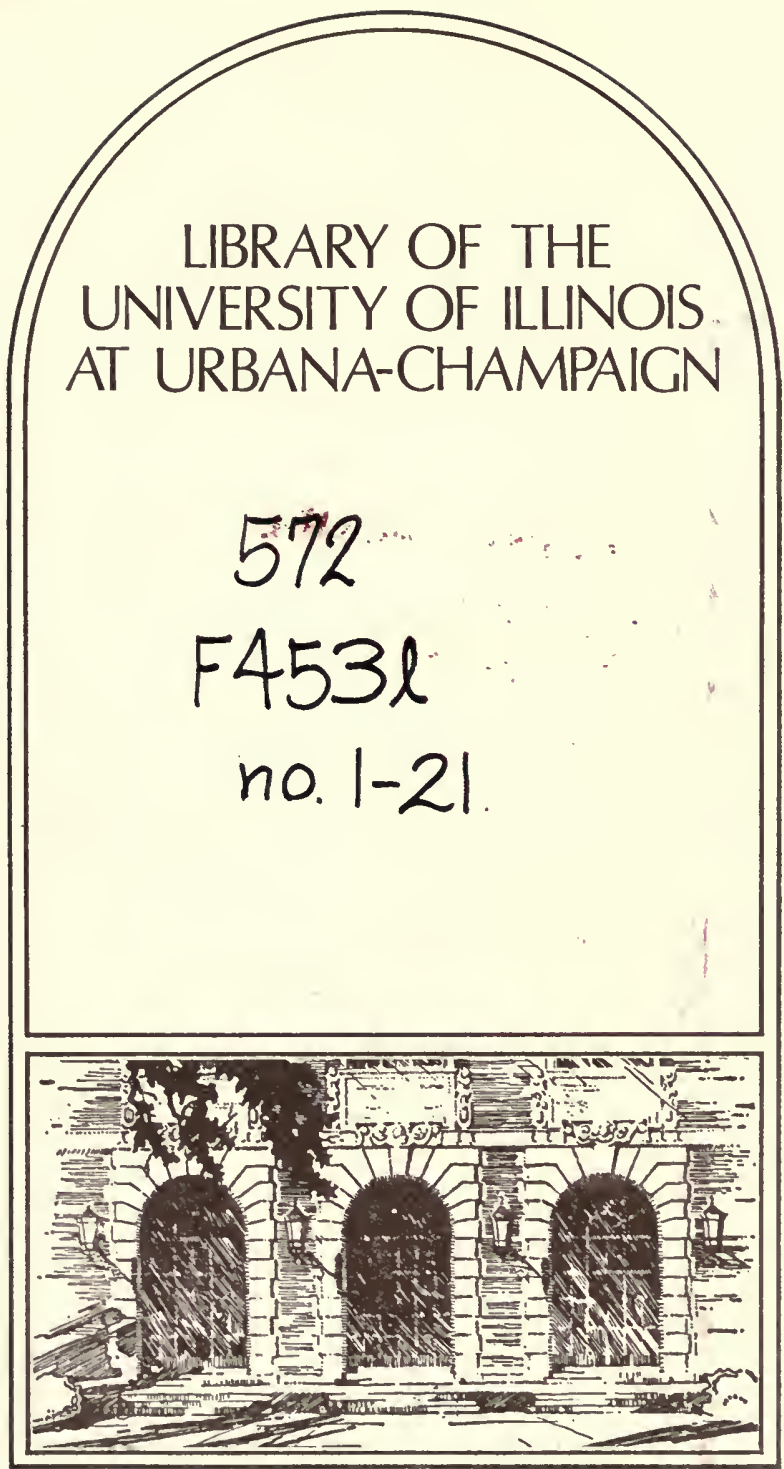


The person charging this material is responsible for its return to the library from which it was withdrawn on or before the Latest Date stamped below.

Theft, musilation, and underlining of books are reasons for disciplinary action and may result in dismissal from the University.

To renew cail Telephone Center, 333-8400

UNIVERSITY OF ILLINOIS LIBRARY AT URBANA.CHAMPAIGN =

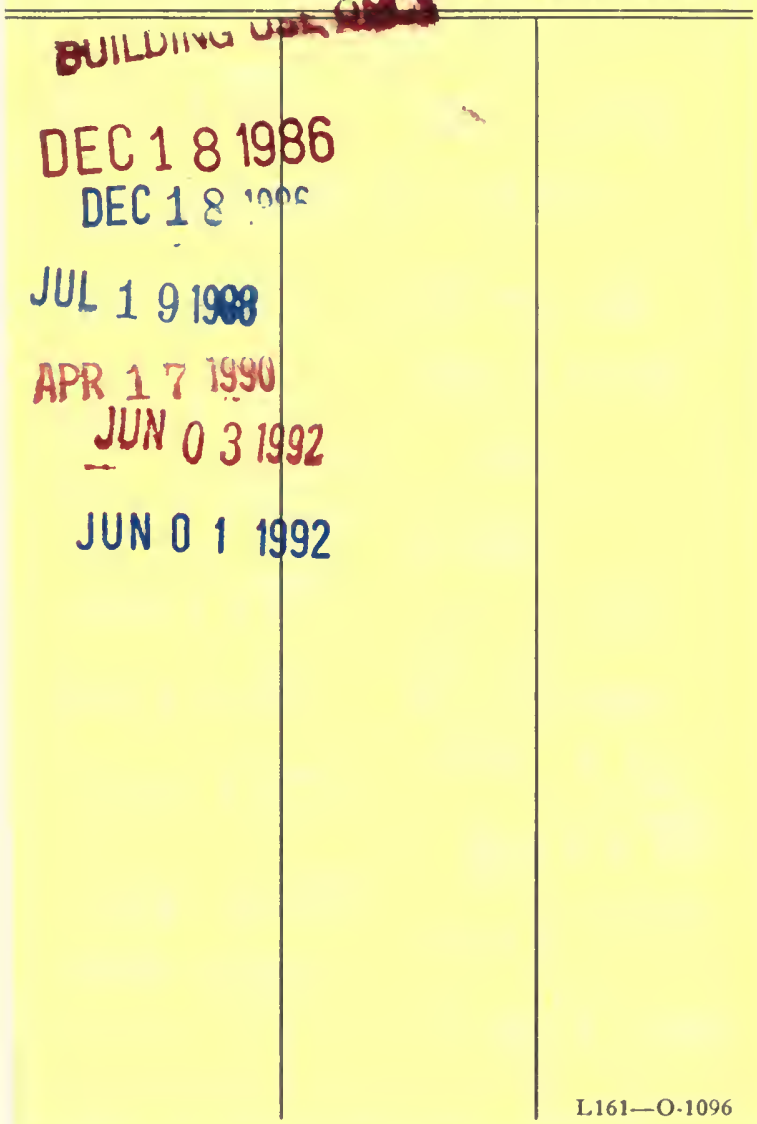







\section{THE CHINESE GATEWAY}
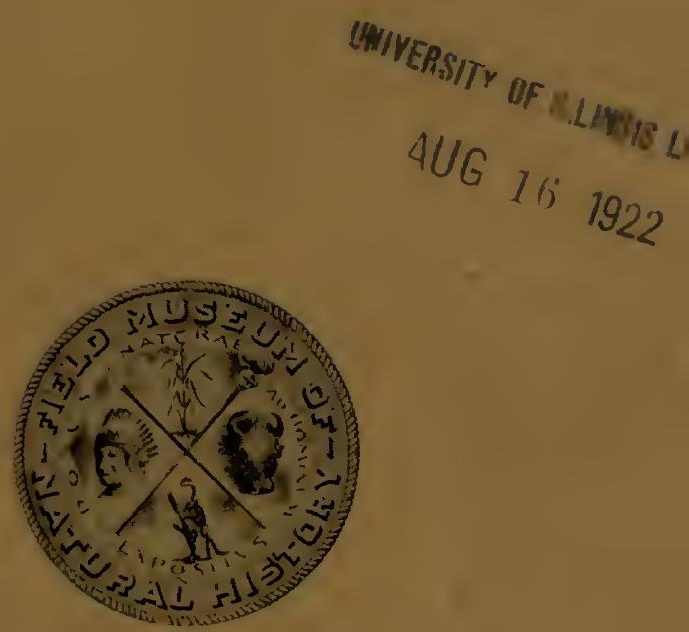

FIELD MUSEUM OF NATURAL HISTORY CHICAGO 



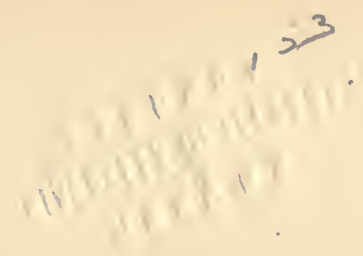

\section{THE LIRRARY}

of Ting

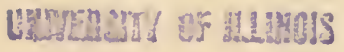



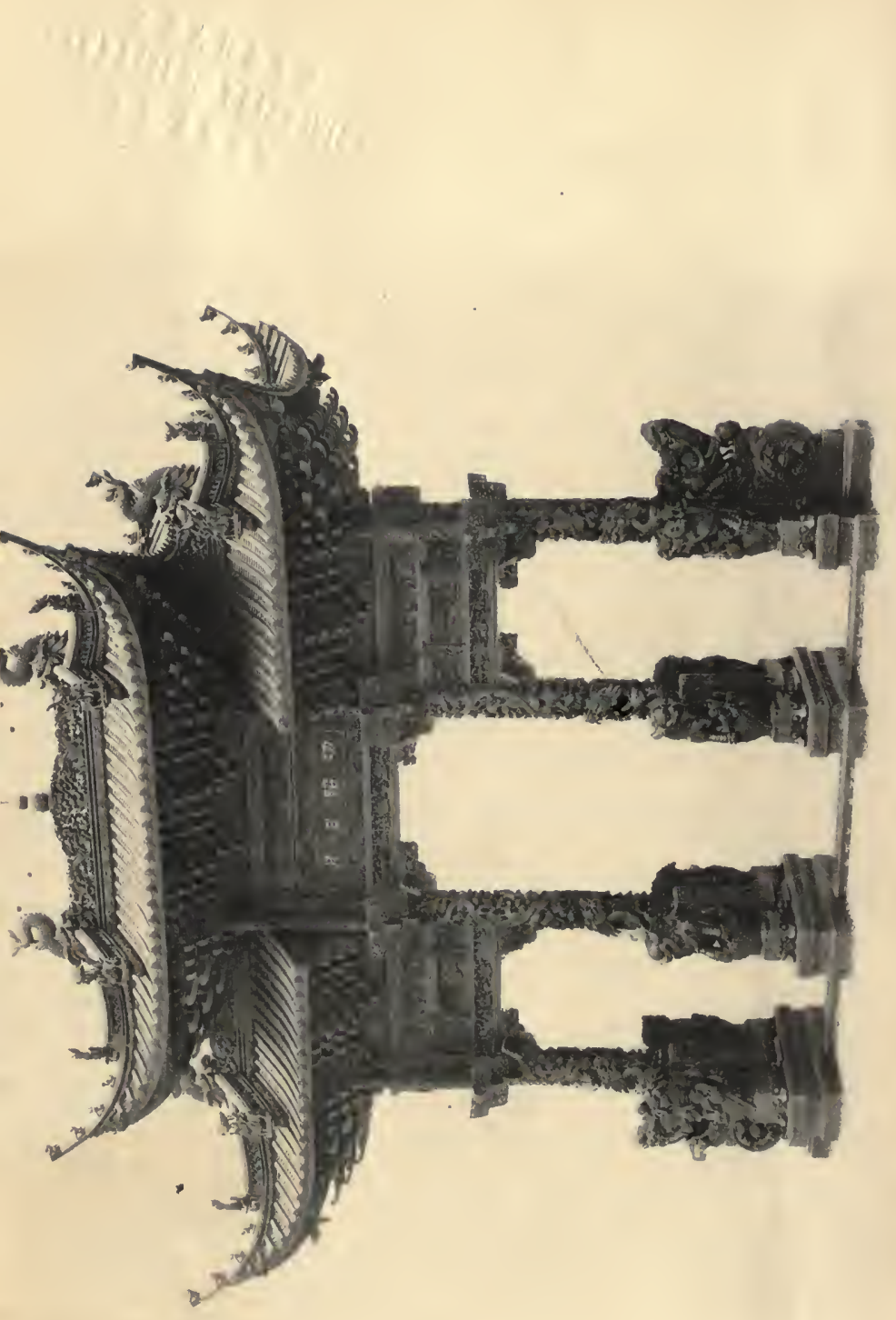


\section{$F 453 l$ \\ no. $1-21$}

Field Museum of Natural History

DEPARTMENT OF ANTHROPOLOGY

Chicago, 1922

\section{The Chinese Gateway}

(At South End of Stanley Field Hall)

Large gateways of high architectural order occupy a prominent place in the streets of Chinese cities, in the courtyards of temples, or on avenues leading to a tomb or mausoleum. As a type of architecture, they are based on the so-called Torana of India, plans of which were introduced into China and Japan as a sequel of Buddhism. In the Buddhist art of ancient India, ornamental stone rails were built as enclosures around the topes (mounds or structures containing sacred relics), four gateways of highly decorative style being placed in these rails. The Chinese, however, did not slavishly imitate these monuments, but merely took them as models and lavished on them the wealth of their own decorative motives.

While the Romans erected triumphal archways in commemoration of military successes, while the people of India built them. in honor of their greatest man, Buddha, the minds of a philosophical nation like the Chinese drifted in a different direction. The exaltation of military victories had no room in their thoughts; they raised sanctuaries to glorify their philosophers and statesmen, their sages and scholars, who shaped and advanced the mental and ethical culture of the nation. The character of Chinese art is impersonal, nor does it glorify the individual. China has no statues or portraits of emperors and generals.

Honorary gateways were erected in memory of deserving servants of the state and virtuous women. Widows, who did not remarry after their husband's 
death, and who faithfully nursed their parents-in-law, were entitled to this honor; likewise children for unusual acts of filial piety, persons who had reached the age of one hundred, and statesmen for loyal devotion to the throne. If such a canonization was recommended, the emperor, on receiving the petition, issued a "holy edict," which was chiseled in stone on the top of the monument, and he contributed the sum of thirty ounces of silver. The balance of the cost was subscribed by the family of the honored person or by the grateful community. The ideal purpose of these gateways, accordingly, was to perpetuate to posterity the memory of excellent men and women and to act as an influence on the conduct of the following generations.

The number of openings or passages in gateways is usually three, as in the gateway of the Museum, while more rarely five arches occur. Such may be seen, for instance, on the tomb of Confucius in Shantung or on the avenue leading to the mausoleum of the Ming emperors, north of Peking. Marble, granite, sandstone, and wood are employed for gateways. Wooden structures, as a rule, are less elaborate than those of stone. The gateway shown in the Museum is a very exact reproduction in teakwood of one in stone, with all the rich details of ornamentation.

The harmonious construction, the ingenious composition, the pleasing proportions, and skill in workmanship, are notable features. The four pillars are each adorned with a powerful, scaly dragon, rising from the depths of the sea heavenward into clouds and making for a flamed pearl: the aspiration for an ideal that is set before man, but that can never be reached. The pedestals carry figures in the round of lions playing with their young; altogether forty-two lions are represented. It is remarkable that each and every lion is different in posture and action. Some are provided with collar-bands and bells; some have their manes rolled up in spirals, 
while others have two bearded tips. In some, the eyebrows are conventionalized into spiral designs; in others, they hang over the eyeballs. In the two corners is represented a drum on each side of which are shown three lion-cubs chasing a ball.

A great deal of symbolism is connected with the lion. The Chinese recognize him as the king of all beasts, and his roaring dispels phantoms. Under the imperial régime, the Grand Preceptor of the emperor and his assistant occupied a high rank among the state-officials, for it was the duty of these functionaries to inculcate in the heir-apparent the maxims of good government and conduct. Being called $t$ 'ai shi ("grand preceptor") and shao shi ("small preceptor"), a pun was easily suggested by the designation of the lion, which likewise is $s h i$. Thus the representation of a large and a small lion intimates the wish, "May you obtain the position of the first and second dignitary at the imperial Court!" Again, the lions engaged in playing ball symbolize the peace and prosperity of the empire. In this case, the lions represent military officers, who are not obliged to go to war, but who indulge at home in the harmless sport of ball-playing.

The inscription, consisting of eight gilded characters (four on each side) and set off from a diapered background, reads, -

"Your merits shine like sun and moon,

"Your good deeds vie in extent with streams and mountains."

This panel is bordered by a pair of dragons on the upper and lower sides and by the figure of a phœnix to the right and left.

The principal and most conspicuous portion of any Chinese structure is the roof. In a private mansion, it is the index of the owner's taste and social standing. In a public building, it indicates at once its peculiar character; and, according to the simplicity, grandeur, 
massiveness, vigor, or elegance of construction, as the case may be, foreshadows its scope and importance. Color symbolism expressed by the hues of the glazed tiles is another means of identification. In the gateway, each passage is surmounted by a roof of its own, the three roofs being so organically connected that the impression is conveyed of a double roof. The graceful, picturesque curves on the corners ("flying eaves," as they are styled by the Chinese) are each surmounted by four lions, believed to be faithful guardians and to ward off evil influences from the monument.

The roof is supported by eight struts (four on each side), carved into the appearance of bamboo stems with exuberant foliage. Rafters and tiling are so skilfully brought out in the woodwork as to inspire a perfect illusion. Sixteen carvings of figures in the round are displayed over the roof: they represent military officers, eight on horseback, and eight on foot, each in full armor, equipped with spears, halberds, clubs, and other weapons, and attended by footmen holding flags.

The ridge-pole is adorned with a panel carved in open work with two dragons struggling for the flamed pearl, and surmounted by a calabash. The latter is an emblem of the creative power of nature, of fertility and abundance (corresponding to our horn of plenty). The Taoist adepts used calabashes to store the elixir of immortality, and druggists preserve their medicines in them or in gourd-shaped vials. The ridge-poles are flanked by dolphins, head downward and tail upward, the belief being entertained that they safeguard the structure from conflagration. The wooden balls supported by wires are intended for water bubbles rising from the clouds by which the dragons are enveloped.

In the dragon-columns the favorite personages of Taoist mythology are represented. On the two inner columns we note the so-called Eight Immortals, bestow- 
ing on mankind old age and all sorts of blessings: Chang Kuo with his magic wand capable of fulfilling his every wish; Ts'ao Kuo-k'iu with his castanets, by means of which he performs magical feats; Chung-li Küan with his fan; Han Siang-tse blowing his flute; Lü Tung-pin with a magic fly-whisk and sword on his back; the beggar Li T'ie-k'uai with a calabash full of blessings; Lan Ts'ai-ho with a flower-basket; and the fairy Ho Sien-ku with the stem of a lotus, the sacred emblem of purity. Compare the two sets of bronze images of the Eight Immortals in Blackstone Chinese Collection, Case 21.

On the two outer columns are portrayed two Taoist sages or hermits, one shouldering a branch with peaches, which ripen but once in three thousand years in the paradise of the goddess Si Wang $\mathrm{Mu}$, and which confer immortality on the adepts of Taoism, and two fairies with miraculous fly-brushes. It was the belief of the Taoists that contact with nature, a contemplative life in the solitude of mountains, is conducive to purification, old age, and speedy salvation; in this manner the soul ultimately is capable of soaring heavenward on the wings of a crane. Thus we see two recluses astride cranes carried upward at the end of their earthly career. In the lower portions of the outer pillars are figured the gay twin genii of Union and Harmony; one, holding a covered jar from which emanates a tree covered with money; the other, a lotus. These emblems are suggested by punning, both the lotus and a jar being called ho, and two other words ho being expressive of the notions "union" and "harmony."

Other Taoist symbols are illustrated in the panels on the pedestals. One of these shows a crane soaring in clouds above a pine-tree,- both being symbols of endurance and longevity - and a deer, which is emblematic of high official dignity and good income. Another represents a phœnix alighting upon the beautiful $\mathrm{Wu}-$ 
t'ung tree (Sterculia platanifolia), famed in legend and art, and the unicorn Kilin, the emblem of perfect good, that appears only at the birth of a virtuous ruler.

The high-relief carvings that decorate the horizontal lintels above the passages carry us back to realistic scenes of human life. They are arranged so that warlike scenes are assembled on one side of the gateway, while representations of peaceful pastimes occupy the opposite side. The main themes of the artist are tournaments of ancient paladins, thrusting halberds or spears at one another in front of a city-wall, from the rampart of which other grandees eagerly watch the spectacle. Or a cavalier turning backward on his galloping steed sends an arrowat his adversary, whose helmet is pierced by it, while tents surrounded by standards lend color to the background of the military action. The genrescenes depict the tribunal of a high official, old men enjoying themselves in a grove, a lady travelling in a push-cart and escorted by mounted lancers, or a monk conducting a dignitary to the gate of his temple, which bears the name "Temple of Sweet Dew" (Kan-lu-se).

There are altogether twenty-two corbels, sixteen being decorated with designs of a phœnix, and six with interesting scenes describing the pastimes of cultivated gentlemen of leisure, as follows:-Feeding ducks, enjoying a cup of wine in a grove of pine-trees, writing a poem on a rock, painting a bamboo sketch on a scroll, reading in the woods at a table formed by a bowlder, playing the lute, dancing around a rock, taking a stroll in the company of a youth, who carries a pot of peonies, playing checkers on a stone board, planting flowers in a bed, examining the growth of plants, going a-fishing with a long rod over the shoulder.

It will thus be seen that the art displayed on this gateway is a marvelous embodiment of Chinese life and thought, a record of cosmogony and mythology, of heaven and earth. 
The gateway is carved from teakwood, being 19 feet in height and 16 feet 9 inches in width. It was made in the Chinese Orphanage of Sikkawei, a Jesuit institution, near Shanghai, and was first on exhibition in the Palace of Education at the Panama Pacific International Exposition of San Francisco.

B. LAUfer 


\section{GIVERSTT OF HLLMOIS LIBRhYY}

$$
\text { AUG } 16 \quad 19^{5} 2 \%
$$





UNIVERSTTY OF RLINOIE-URBANA 